\title{
MASS PROPAGATION OF LUNUMIDELLA Melia dubia USING INVIVO AND INVTRO CULTURE METHODS
}

\author{
Visaka Seedevi Mapa, S E Peries and B C N Peiris \\ Department of Crop Science, Faculty of Agriculture \\ University of Peradeniya
}

Lunumidella (Melia dubia) is a fast growing short rotational tree species which can be harvested in 15-20 yrs. The timber is light and mainly used for ceilling and panelling. However due to the presence of a hard seed coat and limited period of viability planting of Lunumidella has become a problem.

Therefore investigations were carried out with the objective of finding suitable propagation techniques using invivo and invitro culture methods. Shoot tip culture method was carried out using axillary buds and nodel segments taken from plant materials brought from the Dodangolla University farm and kept under the running tap water for 2 hours. Then surface sterilization was done using 10\%. Naocl containing 2 drops of teepol/100ml solution for $10 \mathrm{mts}$. in sterilized conditions. They were then washed with distilled water 3 times for $2 \mathrm{~min}$. each and transferred into Mureshige and skoog medium (MS) containing different concentrations of cytokinins.

The best medium to grow Lunumedella invitro was $1 / 2$ strength Ms Agar medium with the supplement of $1.0 \mathrm{mg} / \mathrm{l} \mathrm{BAP}$.

\section{In vivo methods}

Different pretreatment methods were adopted to overcome the poor germination due to the hard seed coat by using acid treatments, base treatments, heat treatments and mechanical scarification. Seeds were treated with $98 \% \mathrm{H}_{2} \mathrm{SO}_{4}$ for different time periods; $1 \mathrm{mt}, 5 \mathrm{mts}$, $10 \mathrm{mts}, 15 \mathrm{mts}, 30 \mathrm{mts}$ ) and then soaked in water for 24 hours and planted them in poly bags in the plant house.

Likewise the same procedure was carried out with base $\mathrm{Ca}(\mathrm{OH})_{2}$ and $\mathrm{KOH}($ ash).

The best pretreatment method for Lunumidella was acid pretreatment method. In this case the germination percentage was $40 \%$.

Proceedings of the Third Annual Forestry Symposium 1997, of the Department of Forestry and Environmental Science, University of Sri Jayewardenepura, Sri Lanka 